Sains Malaysiana 50(11)(2021): 3205-3217

http://doi.org/10.17576/jsm-2021-5011-05

\title{
Petrography and Geochemistry of Dolomites of Samanasuk Formation, Dara Adam Khel Section, Kohat Ranges, Pakistan
}

(Petrografi dan Geokimia Dolomit Formasi Samanasuk, Bahagian Dara Adam Khel, Kohat Ranges, Pakistan)

\author{
Emad Ullah Khan, Abbas Ali Naseem* Maryam Saleem, Faisal Rehman, Syed Waseem SaJjad, Waqar \\ AHMAD \& TAHIR AZEEM
}

\begin{abstract}
Replacement dolomite occurs in Jurassic Samanasuk Formation in Dara Adam khel area of Kohat ranges, NorthWestern Himalayas, Pakistan. This study, for the first time, document the process of dolomitization and evolution of strata bound dolomitic bodies. Field investigation, petrography and geochemistry helped in unraveling the formation of several dolomitic bodies. Petrographically dolomites comprises of: (1) medium grain crystalline planer subhedral dolomite (Dol-I); (2) fine grained crystalline anhedral non-planer dolomite rhombs (Dol-II); (3) medium to coarse grained crystalline subhedral-anhedral non-planer dolomite (Dol-III) and coarse to very coarse grained crystalline saddle dolomite cements (SD). The saddle dolomites (SD) postdate the replacement dolomites and precede telogenetic calcite (TC) cements. Stable $O$ and $C$ isotope analysis shows that these dolomites have $\delta^{18} \mathrm{O}_{\text {vpdb }}$ ranging from $-4.09 \%$ to -10.4 whereas the $\delta^{13} C_{v p d b}$ ranges from +0.8 to +2.51 . Major and trace elements data show that Sr concentrations of 145.5 to 173 ppm; Fe contents of 2198 to 8215 ppm; and Mn contents of 93.5 to 411 ppm. Petrographically replacive dolomites, saddle dolomite, and $\delta^{18} O_{v p d b}$ values depicts neomorphism of replacement dolomites that were formed earlier were exposed to late dolomitizing fluids. As a result of basin uplift during the Himalayan orogeny in Eocene time, dolomitization event was stopped through occurrence of meteoric water. The Main Boundary Thrust (MBT) and its splays were most likely essential conduits that channelized dolomitizing fluids from siliciclastic rocks that were buried deeply into the Jurassic carbonates rocks, leading to more extreme dolomitization.
\end{abstract}

Keywords: Dolomitization; hydrothermal; isotope; saddle dolomite

\section{ABSTRAK}

Dolomit penggantian berlaku dalam Formasi Jura Samanasuk di kawasan khel Dara Adam, banjaran Kohat, Barat Laut Himalaya, Pakistan. Kajian ini, buat pertama kalinya, mendokumentasikan proses pendolomitan dan evolusi jasad dolomitik terikat strata. Penyelidikan lapangan, petrografi dan geokimia membantu merungkai pembentukan beberapa jasad dolomitik. Dolomit petrografi terdiri daripada: (1) dolomit subhedron perata kristal butiran sederhana (Dol-I); (2) rombus dolomit bukan perata anhedron kristal butiran halus (Dol-II); (3) dolomit bukan perata subhedron-anhedron kristal butiran sederhana hingga kasar (Dol-III) dan simen dolomit pelana kristal kasar hingga kasar (SD). Pelana dolomit (SD) menunda penggantian dolomit dan mendahului telogenetik kalsit (TC) simen. Analisis isotop $O$ dan $C$ yang stabil menunjukkan bahawa dolomit ini mempunyai $\delta 180 v p d b$ antara $-4.09 \%$ hingga -10.4 sedangkan $\delta 13 C v p d b$ berkisar antara +0.8 hingga +2.51 . Data unsur utama dan unsur surih menunjukkan bahawa kepekatan Sr dari 145.5 hingga 173 ppm; kandungan Fe dari 2198 hingga 8215 ppm; dan kandungan Mn 93.5 hingga 411 ppm. Nilai dolomit pengganti petrografi, dolomit pelana dan nilai $\delta 180 v p d b$ menggambarkan neomorfisme penggantian dolomit yang terbentuk sebelumnya terdedah kepada cecair pendolomitan lewat. Akibat peningkatan lembangan semasa orogeni Himalaya pada usia Eosen, peristiwa pendolomitan dihentikan akibat terjadinya air meteor. Sungkup Sempadan Utama (MBT) dan megarnya kemungkinan besar merupakan saluran penting yang menyalurkan cecair pendolomitan daripada batuan silisiklastik yang terkubur jauh ke dalam batu karbonat Jura, menyebabkan pendolomitan yang lebih ekstrem.

Kata kunci: Hidroterma; isotop; pendolomitan; pelana dolomit 


\section{INTRODUCTION}

Globally, more than $50 \%$ of carbonate rocks are important hydrocarbon reservoirs, particularly dolomite rocks (Dickson 1966; Kakemem et al. 2021; Montaron 2008), therefore, they have been the main attention of research and exploration for a huge span of time. The dolomites are formed by replacement of $\mathrm{Ca}^{2+}$ with $\mathrm{Mg}^{2+}$ within the calcite mineral lattice. This replacement affects the volume and crystalline nature of the formed dolomite (Braithwaite et al. 2004; Hsü 1967). In general, it is impossible to synthesize dolomite under laboratory conditions, as for the process of dolomitization it requires $\mathrm{Mg}$ from a peripheral source and normal sea water is the only source which provides abundant $\mathrm{Mg}$ (Bontognali 2008; Fairbridge 1957; Land 1998; Purser et al. 1994). Even though a chain of dolomitization models particularly evaporative, seepage-reflux, microbial-mediated and burial dolomitization have been recommended to explain the source of these massive dolomite bodies of different ages in numerous geological settings (Mazzullo 1992), yet it is still not fully understood. According to various authors, the dolomite is formed at abnormal temperature (i.e. temperature $>$ ambient temperature of host rock) is termed as hydrothermal dolomites (Machel \& Lonnee 2002; Swennen et al. 2012; White 1957). During the past several years, existence of dolomite related to hydrocarbon reservoirs made the way to widespread studies of dolomitic bodies that are formed through various procedures (Sibley \& Gregg 1987). Extra studies are still required to better comprehend the controlling aspects that effect the rock behavior in dolomitic bodies. Various techniques have been used for the evaluation of the dolomites worldwide. The formation of dolomite by the process of evaporation in Lower-Middle Ordovician cyclic carbonates in northern Tarim Basin, NW China (Chuan et al. 2017). Similarly, many authors proposed burial dolomitization model for various dolomitic units (Martín-Martín et al. 2013; Swennen et al. 2012). However, tectonic driven or structurally controlled dolomite characterizes such dolomites that require additional detailed studies to describe associated replacement processes (Gomez-Rivas et al. 2012). Several authors produced various characteristics of tectonic driven fault-related dolomitic bodies, particularly straightening out the fluid flow mechanism liable for the process of dolomitization (Davies \& Smith 2006). Moreover, the link concerning diagenetic alterations that lead to several dolomite phases and their influence on reservoir properties has also been debated (Fu et al. 2006). The distributions of these dolomitic bodies in general monitor the movement of the feeding faults (pathway for dolomitizing fluid), but these dolomitic bodies favor appropriate beds where dolomitizing fluid flow through more permeable beds as they deviate from the fault and later lead to beddingparallel dolomitization or stratum-bound dolostones (Lucia $\&$ Major 1994). In order to recognize the formation of different diagenetic phases in the strata bound dolomites a detailed field examination is necessary. The present work is the first study of the dolomites based on detailed macroscopic and microscopic petrographic examinations, and geochemistry of the stratabound dolomites in Jurassic Samanasuk Formation in Dara Adam village, Kohat ranges. Previously, Samanasuk Formation was studied in detail in respect of its sedimentology, paleontology, and stratigraphy (Wadood et al. 2021). Moreover, paleoenvironments, paleoclimate, paleoenergy, and paleosalnity for Samanasuk Formation in Hazara region was documented (Saboor et al. 2020). The microfacies related depositional environment and diagentic evolution was determined in Nizampur, Attock-Cheart Ranges (Ullah Khan et al. 2020). However, the dolomites are widely distributed in the rock unit, and are not yet fully understood. Therefore, this paper aimed to document the petrography of strata bound dolomitization and to define the geochemical characteristics of the dolomitizing fluids that caused dolomitization.

\section{GEOLOGICAL SETTING}

The northward movement of Indian plate from the Gondwanaland occured about $130 \mathrm{Ma}$ ago which lead to the retrenchment of the Neo-Tethys that was located between Indian plate and Eurasian plate (McKenzie \& Selater 1973; Rehman et al. 2011). During the Paleocene and Eocene time the collosion between Indian and Eurasian plate resulted in Himalaya orogeny in North Pakistan due to which Indus-Tsangpo suture zone was formed (Chatterjee \& Bajpai 2016; Chatterjee et al. 2013; Henderson et al. 2011; Leech et al. 2005; Wadood et al. 2020). This suture splits into the Main Mantle Thrust (MMT) and Main Karakoram Thrust (MKT) in North Pakistan (Rehman et al. 2011; Tahirkheli 1979). In late Cretaceous, a terrane was formed an Island arc (Kohistan Islanad arc) that occurred to the north of MMT which was sandwiched with Eurasian plate along the MKT to the North (Alam 2008; Chatterjee \& Scotese 2010; Rehman et al. 2011). In North Pakistan, the Main Boundary Thrust (MBT) shows the frontal region of lesser Himalayas mountain range. This Main Boundary Thrust bring Mesozoic to Cenozoic rocks of Kohat, Kalachitta and 
Margalla hill ranges to the surface, tectonically overlying rocks that are deposited in the adjacent Potwar and Kohat basin (Khan et al. 1986; McDougall et al. 1993; O'Brien et al. 2001). The tectonic map with the location of the study area lies in Kohat near Dara Adam Khel which are classified by composite set of structures as shown in Figure 1(a).

The tectonic setup in the study area is characterized by thrust tectonics as the faults and folds are formed due to compressional stresses due to the movement of the Indian Plate towards north (Ghauri et al. 1983; Yaseen et al. 2021). The leading thrust fault in the study area is the Main Boundary Thrust fault (MBT). This fault has thrusted the Jurassic rocks over the Miocene rocks to the south and Paleocene rocks to the north (Ghauri et al. 1983; Yaseen et al. 2021). The study area is divided into three diverse structural zones due to indefinite variation in the outline of deformation and also has change in the nature, mechanical retort and age of rocks (Yaseen et al. 2021). In the Kohat basin the Paleogene to Mesozoic rocks are thrusted over the Eocene to Miocene strata along the MBT. Startigraphically Jurassic to Miocene age rocks are present in the study. These rocks include Samanasuk, Chichali, Lumshiwal, Kawagarh, Lockhart, Patala, Panoba, Kohat, and Murree Formations that are strongly folded into E-W trending Anticlines and Synclines (Ghauri et al. 1983; Yaseen et al. 2021). The generalized stratigraphy of the Kohat region is shown in Figure 1(b).

\section{MATERIALS AND METHODS}

Field investigations were carried out in the study area to sample dolomite unit and different diagenetic phases. Random as well as systematic sampling was carried out to cover the whole stratigraphic sequence. Thin sections of the selected representative samples of dolomites were prepared in the sedimentology department of the Hydrocarbon Development Institute of Pakistan (HDIP) Islamabad. These thin sections were then studied for petrographic observations on Olympus CX41 with digital camera Olympus DP21 fitted in the Department of Earth Sciences, Quaid e Azam University Islamabad. Elemental composition of 22 samples were done using Atomic absorption spectroscopy in National center of excellence in geology, Peshawar. Stable oxygen and carbons isotopic analysis of various dolomite and calcite phases were carried out in Pakistan Institute of Nuclear Science and Technology (PINSTECH) Islamabad. The stable isotope values are expressed in per mill (\%) relative to Vienna Pee Dee Belemnite (V-PDB) by assigning a $\delta^{13} \mathrm{C}$ value of $+1.95 \%$ and a $\delta^{18} \mathrm{O}$ value of $-2.20 \%$ to NBS 19 . The carbonate powdered samples were reacted with $100 \%$ phosphoric acid (density $>1.9$ ) at $75^{\circ} \mathrm{C}$ in a Kiel III online carbonate preparation line (Carbo-Kiel-single-sample acid bath) connected to a ThermoFinnigan 252 mass spectrometer. Reproducibility was checked by replicate analysis of laboratory standards and is better than \pm 0.05 $(1 \sigma)$. Dolomite isotopic composition values were corrected using fractionation factors given by Rosenbaum and Sheppard (1986).

\section{FIELD OBSERVATIONS}

Field observations showed that the host limestone and dolomitic bodies of various thickness are interbedded with each other in Dara Adam khel village in Kohat ranges (Figure 2(a)). The dolomite can be identified and recognized from limestone by variation in color present between their exposed surfaces where limestone of Samanasuk Formation is oolitic in nature (Figure 2(b)), while the dolomites are light brown to dark grey in color having a sharp contact. The dolomitic rocks in the study area were distingushed based on color as well as chopboard weathering in the dolomite which can be clearly seen in Figure 2(c). In the study area, different types of dolomite are observed and identified, these include light grey colored dolomite (Figure 2(d)) and dark grey colored dolomite (Figure 2(e)) and rusty brown dolomite (Figure 2(f)). In the study area, these different types of dolomite were present at contact with each other (Figure 2(g)-2(h)). In addition to matrix dolomite, saddle dolomite (SD) was also observed in brown colored dolomite DolIII as shown in Figure 2(i). Saddle dolomites were formed during late stage diagenesis and as a hydrothermal activity (Davies \& Smith Jr. 2006). The calcite cementation phase postdates dolomitization phases based on crosscutting relationship (Figure 2(j)). In the Samanasuk Formation, stylolites are abundant in the dolomitized rock (Figure 2(d)). The stylolites extend laterally up to few meters along the same layer. There is no specific pattern of spacing between these stylolites, however, in some set of stylolites, a spacing of $4-5 \mathrm{~cm}$ is observed.

\section{PETROGRAPHIC FINDINGS}

Petrographic study establishes a base for defining the correct diagenetic and depositional sequence of the different sedimentological units within a Formation. The variety of dolomite textures depend on the host limestone composition, formation process, time, source 
of dolomitizing fluids (Boggs Jr. \& Boggs 2009). Petrographically four different types of dolomite were identified depending upon the distribution, crystal size and crystal shape (non-planer or planer) (Sibley \& Gregg 1987). These dolomites are: (1) medium-crystalline subhedral planer dolomite (Dol-I), (2) fine crystalline non planar anhedral dolomite rhombs (Dol-II), (3) medium to coarse crystalline subhedral-anhedral nonplaner dolomite (Dol-III), and (4) coarse to very coarse crystalline saddle dolomite cements (SD). Types 1-3 texture of dolomites are replacement dolomite, however type 4 is dolomite cement. Late-stage calcite cements are also present in the dolostones. The Dol-I is mediumcrystalline subhedral planer dolomite which is the first phase of dolomitization as shown in (Figure 3(a)). This dolomite is having crystal size ranging from 60-120 $\mu \mathrm{m}$. The dolomitization process completely destroyed the primary sedimentary structures of the host rock and had preserved the oolitic structure rarely which was the completely destroyed by the second phase of the dolomitization Dol-II (Figure 3(b)). The Dol-I has clear sharp contact with the second stage of dolomitization DolII and is having very less porosity (Figure 3(c)). Dol-II dolomite is fine crystalline euhedral to subhedral crystals. The dolomite shows crystal size of $<10 \mu \mathrm{m}$ and displays planar e-s texture with moderately regular intercrystalline boundaries. The original fabric of the precursor limestone is not preserved. Dol-II shows a clear sharp contact with medium-crystalline subhedral dolomite (Dol-I), moreover vuggy porosity is also evident in this dolomite (Figure 3(d)). The Dol-II is crosscut by white calcite cement (Figure 3(e)) which indicates that the dolomite formation predates the emplacement of calcite cement. Pyrite mineralization is also evident which occurred after the formation of Dol-II as shown in (Figure 3(f)). Medium to coarse crystalline subhedral-anhedral dolomite Dol-III is the third stage of dolomitization having crystal size ranging from $100-150 \mu \mathrm{m}$ and the crystals are having cloudy appearance (Figure $3(\mathrm{~g})$ ). The Dol-III is rare, fabric destructive and has strongly destroyed the original depositional and earlier diagenetic features. The crystals of Dol-III are interlocked with each other and show very less intercrystalline porosity (Figure 3(h)). They commonly exhibit homogenous to weak an undulatory extinction. Latestage telogenetic calcite cross cut the Dol-III (Figure 3(i)). Saddle dolomite cement consists of planar subhedral crystals ranging from 250-1000 $\mu \mathrm{m}$ which generally have a large cloudy core with a thin clear rim. Saddle dolomite cements has a sharp contact with medium to coarse crystalline subhedral-anhedral dolomite
Dol-III (Figure 3(j)). The saddle dolomite appears as pore filling cement in Dol-III (Figure 3(k)-3(l)).

\section{GEOCHEMISTRY}

Major and trace element analysis

A total of 22 samples of different dolomites phases were analyzed for the elemental composition. The abundances of major and trace elements in dolomites, including $\mathrm{Fe}, \mathrm{Mn}, \mathrm{Sr}$, can provide essential evidences to the dolomitization process (Gasparrini et al. 2006). For this purpose, Atomic absorption spectroscopy were carried on selected samples to define the exact chemical composition of the dolomites. Figure 4(a) shows the cross plot of $\mathrm{Sr}$ and Fe concentrations, whereas Figure 4(b) shows cross plot of $\mathrm{Mn}$ and Fe concentrations. The Dol-I dolomites contain an average of $3306.33 \mathrm{ppm}$ of Fe, $159.66 \mathrm{ppm} \mathrm{Sr}$ and $86.16 \mathrm{ppm} \mathrm{Mn}$ concentration. Dol-II has an average of $4675.87 \mathrm{ppm}$ of $\mathrm{Fe}$ concentration which exceeds the concentration in Dol-I. Similarly, the concentrations of $\mathrm{Sr}$ and $\mathrm{Mn}$ are $142 \mathrm{ppm}, 169.56$, respectively. In Dol-III, the concentration of $\mathrm{Fe}$ is two and half times more than Dol-I and II. The average concentration of Fe content in Dol-III is $7853.4 \mathrm{ppm}$. However, the average concentration of $\mathrm{Sr}$ and $\mathrm{Mn}$ in Dol-III is 134.15, 130.9, respectively.

\section{STABLE OXYGEN AND CARBON ISOTOPE ANALYSIS}

Oxygen isotope shows the oxygen signature and temperature of the precipitate solution (sea water, brines or meteoric realm). The oxygen and carbon isotopic signatures of the original seawater precipitate will not be changed if minor neomorphism or burial modification of fibrous calcite occurs. Though when substantial neomorphism occurs the isotopic signatures will form a linear pattern, with the least altered, most marine values, the more positive ones (Given \& Lohmann 1985). Stable oxygen and carbon isotopes analysis of dolomite phases, and white calcite shows isotopically light values compared to the Middle Jurassic original marine signatures that is $-2.8 \%$ to $-1.8 \% \delta^{18} \mathrm{O}_{\mathrm{vpdb}}$ and $+0.0 \%$ to $+1.8 \% \quad \delta^{13} \mathrm{C}_{\mathrm{vpdb}}$ (Fürsich et al. 2004). Stable isotope signatures of the host limestone show isotopically light $\delta^{18} \mathrm{O}_{\text {vpdb }}$ values $\left(-3.34\right.$ to $-4.28 \%$ ), whereas $\delta^{13} \mathrm{C}_{\text {vpd }}$ values range from +1.28 to $+1.71 \%$ as shown in Figure 5. Such isotopically light $\delta^{18} \mathrm{O}_{\mathrm{vpdb}}$ values shows that the limestone is effected by diagenetic fluids, or the rocks are affected by high temperatures as compared to the ambient temperature of the host rock (Shah et al. 2016). The stable oxygen isotopic signatures of Dol-I dolomite ranges from -6.49 to $-4.09 \% \delta^{18} \mathrm{O}_{\mathrm{vpdb}}$ and that of carbon ranges 
from +0.8 to $+2.51 \delta^{13} \mathrm{C}_{\mathrm{vpdb}}$. Dol-II shows comparatively more isotopically light values then Dol-I dolomite but less isotopically lightas compared to Dol-III, saddle dolomite, and white calcite. Oxygen isotopic signatures of Dol-II varies from -8.25 to $-7.45 \% \mathrm{~V}-\mathrm{PDB}$, whereas $\delta^{13} \mathrm{C}$ values ranges from +1.28 to $+1.88 \% \mathrm{~V}-\mathrm{PDB}$. The carbon isotopes signatures are within the range of Jurassic marine signatures. Third phase of dolomitization Dol-III showed the highest isotopically light oxygen values that is -10.41 to $-8.87 \%$ V-PDB and slightly isotopically light carbon signatures +1.54 to $+1.76 \%$ V-PDB, respectively. Moreover, Saddle dolomite (SD) and calcite cement shows high isotopically light oxygen values ranging from -13.27 to $-10.23 \% \mathrm{~V}-\mathrm{PDB}$, however carbon isotope values lies within the range of marine signatures that is +1.3 to $+1.7 \%$ V-PDB.

\section{DISCUSSION}

\section{PARAGENETIC SEQUENCE}

A comprehensive paragenetic sequence of different diagenetic phases has been established based on field observation, petrographic, and geochemical studies (Figure 6) which includes a dolomitization phase and post dolomitization calcitization phase. Initially, after carbonate sedimentation the dolomitization phase resulted in the formation of Dol-I where the oolitic structure is rarely preserved by the Dol-I (Figure 3(b)). Moreover, this is then followed by the second phase of dolomitization which is also evident by the more lighter isotope enrichment values of $\delta^{18} \mathrm{O}_{\mathrm{vpdb}}$. Similarly, Dol-III was formed after the second phase of dolomitization with the highest lighter isotope enrichment values of $\delta^{18} \mathrm{O}_{\mathrm{vpdb}}$. Pyritization occured in shallow to deep burial in reducing conditions (Adams \& MacKenzie 2001). After the formation of dolomites, deformation and dissolution (Figure 3(g)) took place resulting in fracture and pore spaces in these dolomites which were later on filled by saddle dolomite cement (SD) (Figure 2(i)). These different phases of dolomitization indicates multiple episodes of dolomitizing fluids. The dolomitization phase is followed by calcitization phase which resulted in the formation of white calcite (Figure 2(j), 3(i)). The E-W trending fault i.e. MBT and its splays acted as a conduit to the Mg-rich fluids (Shah et al. 2016).

Stable oxygen and carbon isotope signatures of the different dolomites phases shows lighter isotope enrichment values compared to the original sea water marine signatures which implies that dolomitization occurred in different phases. The first phase of dolomitization that is Dol-I, shows medium-subhedral crystals and less isotopically light $\delta^{18} \mathrm{O}_{\mathrm{vpdb}}$ signatures comparative to Dol-II and Dol-III and thus suggest that it formed reltively early under low temprature conditions (Gregg \& Shelton 1990; Sibley \& Gregg 1987). Dol-II and Dol-III which are fine to coarse crystalline anhedral dolomite, respectively, with depleted $\delta^{18} \mathrm{O}_{\mathrm{vpdb}}$ signatures comparative to Dol-I, suggest that they may have formed at somewhat increased temperature as compared to Dol-I (Sibley \& Gregg 1987). The $\delta^{13} \mathrm{C}$ values of these dolomites are not that much far from the original marine signatures of the carbonates thus, the carbon isotopic composition of the dolomitizing fluids likely was protected by the host rock. Moreover, the saddle dolomite (SD) and calcite cement (CC) also displayed highly depleted $\delta^{18} \mathrm{O}_{\text {vpdb }}$ values. Lighter isotope enrichment oxygen isotopic signature of saddle dolomite (SD) cement together with coarse anherdral crystal morphology suggests that dolomitizing fluids originated from greater depths with relatively higher temperatures than the replacive dolomitizing fluids (Davies \& Smith Jr. 2006; Sibley \& Gregg 1987). In addition to that, the dolomite phases show a wide range of $\delta^{18} \mathrm{O}_{\mathrm{vpdb}}$ values which is consistent with multiphase dolomitization (Shah et al. 2016). The different diagenetic phase shows a deviation towards a more negative trend of oxygen-isotope signatures, and increased temperature is the possible source of depleted $\delta^{18} \mathrm{O}$ values. The dolomitization phases are similar to that of Shah et al. (2016) where only 2 phases of dolomitization were identified in the Hazara Basin, whereas in this study multiple phases of deformation in the study area may have caused more then two episodes of dolomitization.

During carbonate diagenesis, $\mathrm{Mn}$ increases and the Sr decreases, as shown in various studies on the alteration extent using the Mn, Sr values (Huang et al. 2003). The low concentrations of $\mathrm{Sr}$ for all dolomite samples are comparable to those of ancient dolomite precipitated from marine waters (Figure 3) (Machel \& Anderson 1989). The elemental composition of different dolomite phases suggests that Dol-III has higher concentration of $\mathrm{Fe}$ and moderate to low concentration of $\mathrm{Mn}$ and $\mathrm{Sr}$ which suggests that this dolomitization occurred at greater depth as compared to Dol-I and II as such reducing conditions are met at depth (Ronchi et al. 2012). The quantity of Fe and Mn content in the late stage diagenetic dolomite Dol-III is higher than that of early dolomitization Dol-I and II. It is because of the fact that Fe and Mn are less concentrated in seawater than in diagenetic 
fluids (Tucker \& Wright 1990). High content of Fe and Mn mostly depends on the reducing nature dominating the environment so that the quantity of $\mathrm{Fe}$ and $\mathrm{Mn}$ in dolomites close to surface, due to the oxidizing conditions, is less than those of burial dolomites formed in reducing environment. Similarly Dol-I is formed at shallow depth as the Fe content is less as compare to Dol-II which also indicates that Dol-II is formed at more depth as compare to Dol-I. The geochemical signatures of these dolomite phases may be alter as a result of subsequent later stage dolomitization events as showing lighter $\delta^{18} \mathrm{O}$ as well as higher Fe-Mn contents suggest shallow burial depth dolomitization (Koeshidayatullah et al. 2020).

\section{DOLOMITIZATION MECHANISM}

Based on field investigation, petrographic studies and geochemical analyses, dolomitization resulted from the circulation of fluids along fractures and faults. These fractures, which later activated or reactivated as MBT during basin inversion, may have provided the probable pathways for deeper source Mg-rich hydrothermal fluids, which is also evident by the presence of Saddle dolomite (SD). Other possible source includes burial associated compactional dewatering of the dolomitizing fluids from deep basinal siliciclastic rocks along the E-W trending MBT. Matrix-replacive dolomite and saddle dolomite look as if to have formed near-contemporaneously and from the same fluid and temperature conditions (Davies \& Smith Jr. 2006). Dol-I and II compared with Dol-III comprises of large dolomite crystals with growing rarely non-planar crystal margins and lesser $\delta^{18} \mathrm{O}_{\mathrm{vpdb}}$ values suggests that Dol-III formed at higher temperatures (Adabi 2009; Chen et al. 2004; Ngia et al. 2019). The overlapping values of $\delta^{18} \mathrm{O}_{\mathrm{vpdb}}$ between various types of dolomites (Figure 5) suggest that the early formed dolomites (Dol-I and II) were neomorphosed by late dolomitizing fluids that is for Dol-III. Likewise, $\delta^{18} \mathrm{O}_{\text {vpdb }}$ values SD dolomite and replacement dolomites also advocate neomorphism of the replacement dolomites when they were open to the later hydrothermal fluids responsible for the precipitation of SD. Moreover, uplifting related to continent-continent collision is shown by the occurrence of telogentic calcite (Figure 3(i)) demonstrating meteoric recharge.

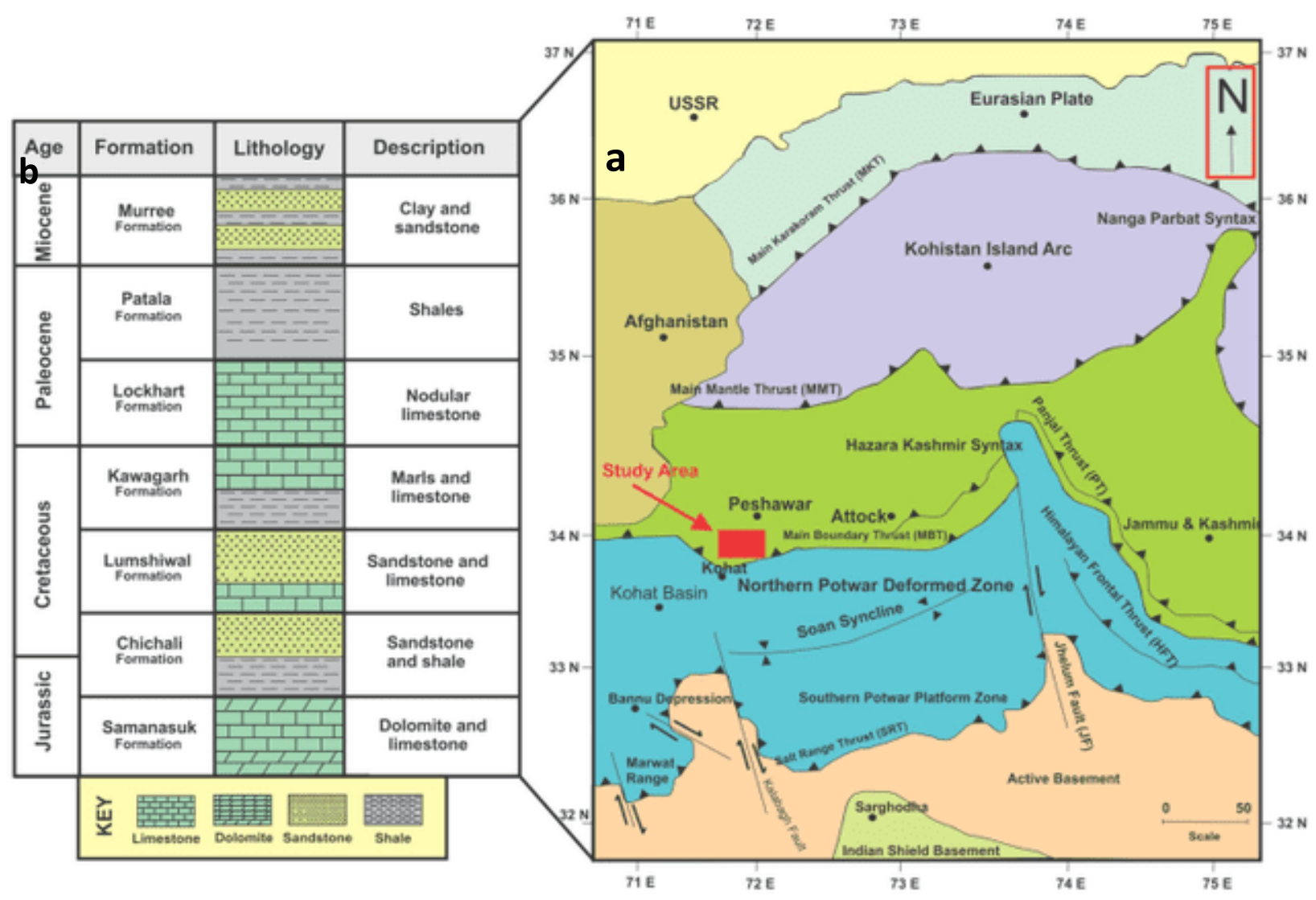

FIGURE 1. (a) Tectonic map with location of the study area lying in Kohat ranges bounded by Peshawar Basin to the north and Main boundary Thrust (MBT) to the south, and (b) Generalized stratigraphy of the study area 


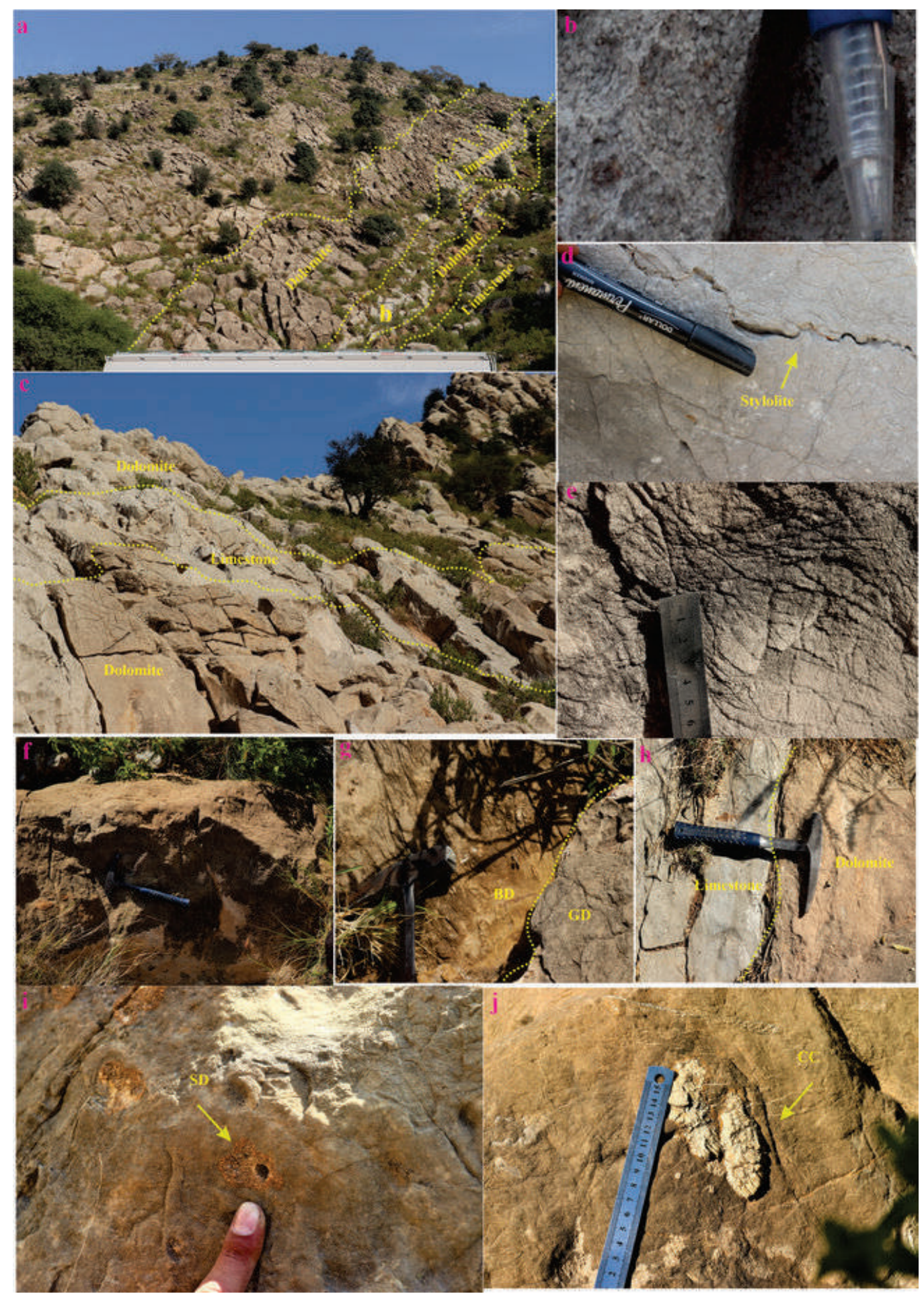

FIGURE 2. (a) Paranomic view of the study area showing stratabound dolomitic bodies in contact with limestone, (b) Oolitic limestone of Samanasuk Formation where the oolites can be clearly seen, (c) Interbedded dolomite and limestone bodies where chopboard weathering can be clearly seen, (d) Light grey colored dolomite Dol-I showing stylolites and chopboard weathering, (e) Dark grey colored dolomite having chop board weathering, (f) Brown colored dolomite (g) Contact between brown colored dolomite (BD) and dark grey dolomite (GD), (h) Contact between limestone and brown dolomite, (i) Brown colored with saddle dolomite (SD) cement, (j) calcite cement (CC) in brown colored dolomite 

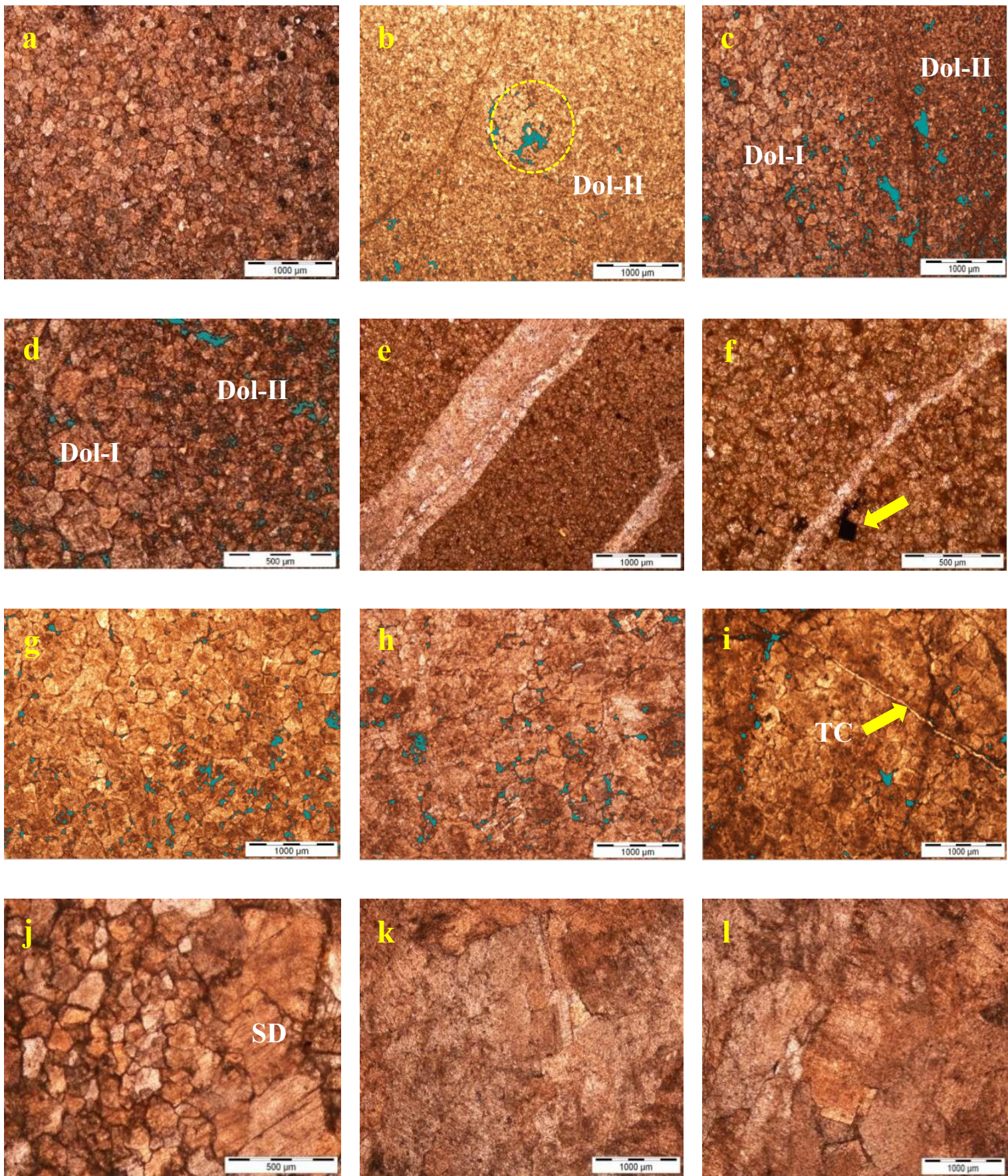

FIGURE 3. (a) Photomicrographs showing medium-grained crystalline subhedral planer dolomite Dol-I, (b) Rarely preserved oolitic structure by Dol-I which is almost destroyed by the second phase of the dolomitization Dol-II, it can be seen that Dol-II has more porosity as compare to Dol-I which is shown by blue color, (c) Contact between different phases of dolomitization that is Dol-I and Dol-II, blue color indicates porosity, (d)

Sharp contact between Dol-II and Dol-I, (e) Calcite cement cross-cutting Dol-II, (f) Pyrite (black rhomb) mineralization indicated by an arrow in Dol-II. The pyrite mineralization postdates the calcite cementation which crosscut the Dol-II phase, (g) Photomicrographs showing medium to coarse crystalline subhedral-anhedral non-planer dolomite Dol-III having cloudy appearance, (h) Interlocked medium to coarse grained crystalline subhedral-anhedral non-planer dolomite Dol-III, (i) Late stage white telogenetic calcite (TC) cement in Dol-III, (j) Irregular contact between saddle dolomite cement with Dol-III, (k-1) Saddle Dolomite cementation showing interlocked crystals 

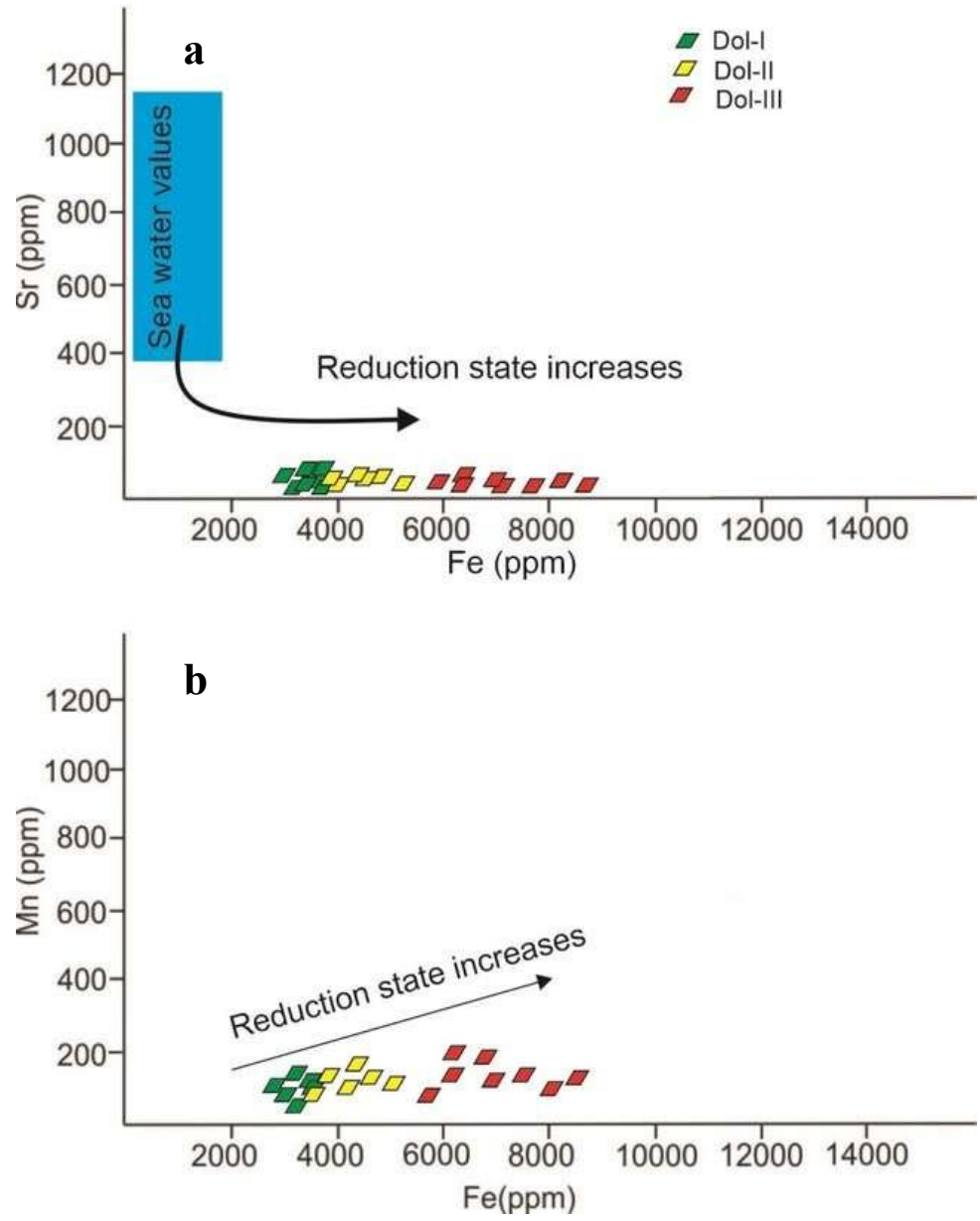

FIGURE 4. Major and trace elements cross-plots (a) Sr and Fe concentrations of different dolomite phases along with sea water values. The Sr content of dolomites is significantly lower than the expected seawater values (Veizer 1983), (b) Enrichment of Fe and Mn concentrations in different dolomite phases

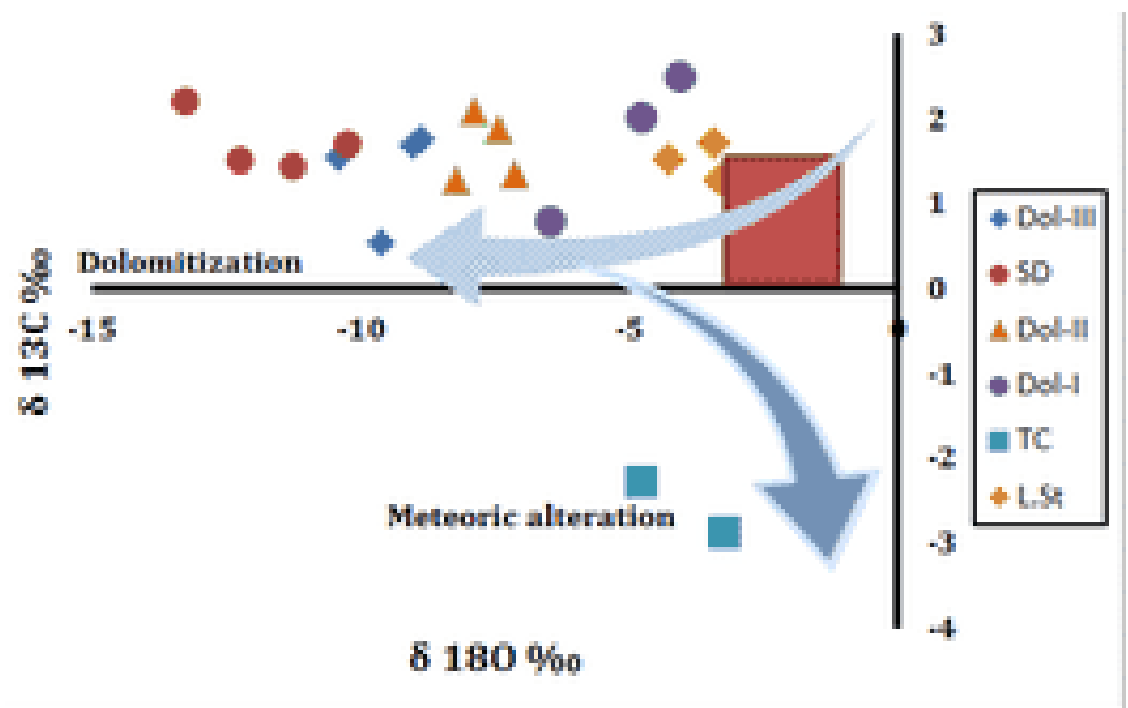

FIGURE 5. Stable isotope signatures showing isotopically light oxygen isotope signatures of different dolomite phases. Moreover late stage telogenetic calcite (TC) exhibited isotopically light carbon signatures 


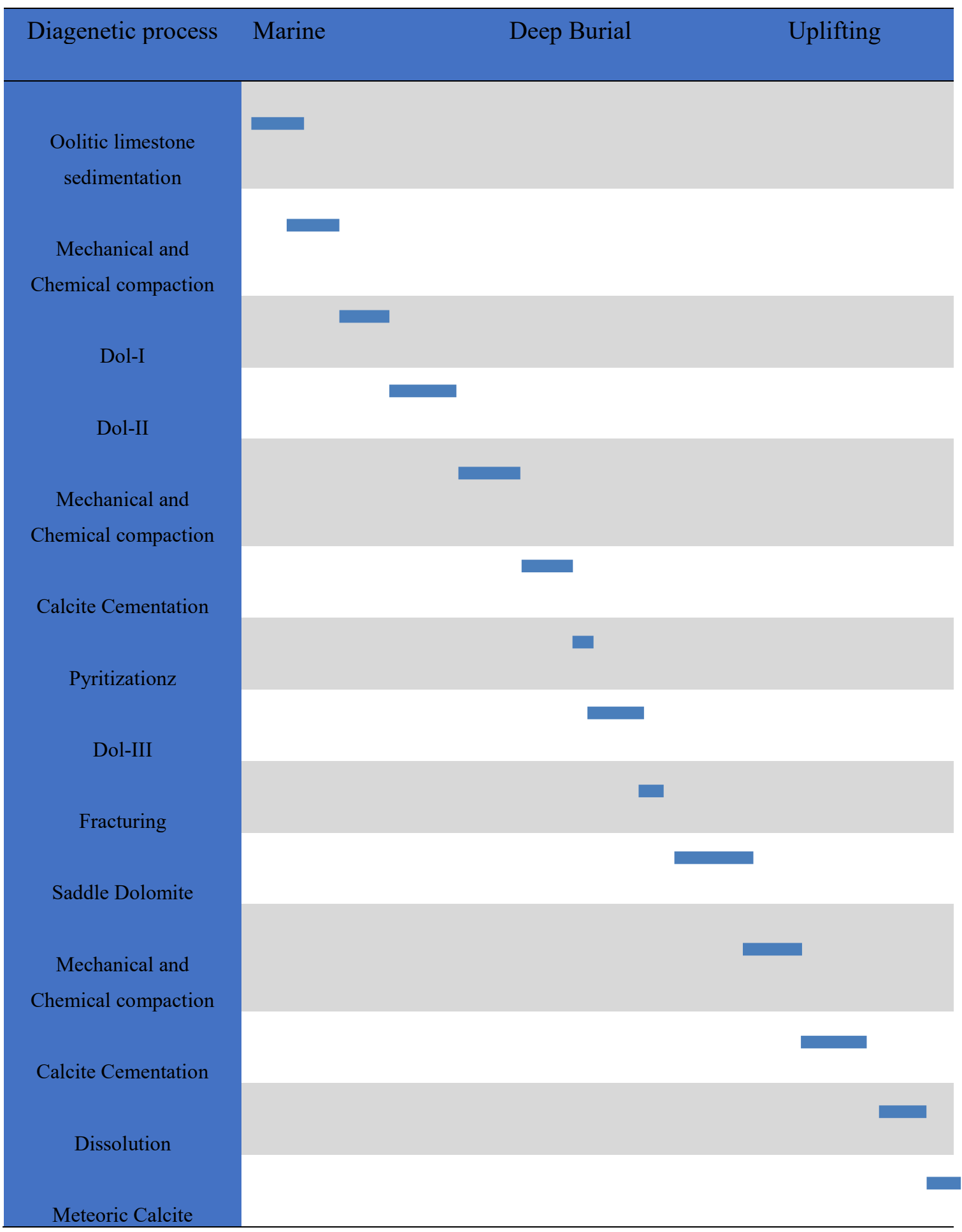

FIGURE 6. Showing detailed paragenetic sequence of the Jurassic Samanasuk Formation 


\section{CONCLUSION}

On the basis of field observations, petrographic, and geochemical investigations of the dolomites in the Dara Adam khel outcrop of Samanasuk Formation in Kohat ranges, the following conclusions are drawn: Three types of dolomites were recognized: (1) Medium-crystalline subhedral planer dolomite (Dol-I); (2) Fine crystalline euhedral to subhedral planer dolomite (Dol-II); and (3) Medium to coarse crystalline subhedral-anhedral nonplaner dolomite (Dol-III). The dolomites are expected to have been formed by the high temperature fluids that moved along the faults and cracks, which may have caused alterations in degrees of dolomitization. This theory explained the presence of cement dolomites in vugs and fractures of matrix dolomites. Based on the oxygen and carbon stable isotope signatures Dol-III may has formed at higher temperature as compared to Dol-I and II, whereas the fluids responsible for the formation of dolomite originated from deep-buried conditions as shown by the more Fe values which shows reducing conditions. On the basis of the proposed research dolomitization model, the research area dolomites were determined to have formed mainly in early stages and were later modified by burial and hydrothermal dolomitization where the faults played an active role as a conduit.

\section{REFERENCES}

Adabi, M.H. 2009. Multistage dolomitization of upper jurassic mozduran formation, Kopet-Dagh Basin, n.e. Iran. Carbonates and Evaporites 24(1): 16-32.

Adams, A.E. \& MacKenzie, W.S. 2001. A Colour Atlas of Carbonate Sediments and Rocks Under the Microscope. London: Manson Publishing. p. 180.

Alam, I. 2008. Structure framework of the Marwat and Khisor range of Pakistan. PhD Thesis (Pub). NCE in Geology University of Peshawar, Pakistan. p. 132 (Unpublished).

Amthor, J.E. \& Friedman, G.M. 1991. Dolomite-rock textures and secondary porosity development in Ellenburger Group carbonates (Lower Ordovician), west Texas and southeastern New Mexico. Sedimentology 38(2): 343362.

Boggs Jr., S. \& Boggs, S. 2009. Petrology of Sedimentary Rocks. Cambridge: Cambridge University Press.

Bontognali, T.R.R. 2008. Microbial dolomite formation within exopolymeric substances, PhD dissertation, ETH ZURICH. p. 141 (Unpublished).

Braithwaite, C.J., Rizzi, G. \& Darke, G. 2004. The geometry and petrogenesis of dolomite hydrocarbon reservoirs: Introduction. Geological Society, London, Special Publications 235(1): 1-6.
Chatterjee, S. \& Bajpai, S. 2016. India's northward drift from Gondwana to Asia during the late Cretaceous-Eocene. Proceedings of Indian National Science Academy 82: 479487.

Chatterjee, S., Goswami, A. \& Christopher, R. 2013. The longest voyage: Tectonic, magmatic, and paleoclimatic evolution of the Indian Plate during its northward flight from Gondwana to Asia. Gondwana Research 23: 238267.

Chatterjee, S. \& Scotese, C.R. 2010. The wandering Indian plate and its changing biogeography during the Late Cretaceous-Early Tertiary period. In New Aspects of Mesozoic Biogeography, edited by Bandopadhyay, S. Berlin-Heidelberg, Germany: Springer-Verlag. pp. 105126.

Chen, D., Qing, H. \& Yang, C. 2004. Multistage hydrothermal dolomites in the Middle Devonian (Givetian) carbonates from the Guilin area, South China. Sedimentology 51(5): 1029-1051.

Chuan, G., Zhao, C., Shaofeng, D., Yixiong, Q. \& Cunge, 1. 2017. Early dolomitisation of the Lower-Middle Ordovician cyclic carbonates in northern Tarim Basin, NW China. Science China Earth Sciences 60(7): 1283-1298.

Davies, G.R. \& Smith Jr., L.B. 2006. Structurally controlled hydrothermal dolomite reservoir facies: An overview. AAPG Bulletin 90: 1641-1690.

Dickson, J.A.D. 1966. Carbonate identification and genesis as revealed by staining. Journal of Sedimentary Research 36(2): 491-505.

Fairbridge, R.W. 1957. The dolomite question: Regional aspects of carbonate deposition. Soc. Econ. Paleont. Mineral. 5: 124-178.

Fu, Q., Qing, H. \& Bergman, K.M. 2006. Dolomitization of the Middle Devonian Winnipegosis carbonates in southcentral Saskatchewan, Canada. Sedimentology 53(4): 825-848.

Fürsich, F.T., Callomon, J.H., Pandey, D.K. \& Jaitly, A.K. 2004. Environments and faunal patterns in the Kachchh rift basin, western India, during the Jurassic. Rivista Italiana di Paleontologia e Stratigrafia 110: 181-190.

Gasparrini, M., Bechstädt, T. \& Boni, M. 2006. Massive hydrothermal dolomites in the southwestern Cantabrian Zone (Spain) and their relation to the Late Variscan evolution. Marine and Petroleum Geology 23(5): 543-568.

Ghauri, A.A.K., Rehman, O. \& Rehman, S. 1983. A new structural model of the southern slopes of kotal pass kohat division, NWFP, Pakistan. Geological Bulletin. University of Peshawar 16: 97-104.

Given, R.K. \& Lohmann, K.C. 1985. Derivation of the original isotopic composition of Permian marine cements. Journal of Sedimentary Research 55(3): 430-439.

Gomez-Rivas, E., Warber, K., Kulzer, F., Bons, P.D., Koehn, D. \& Martín-Martín, J.D. 2012. Structural evolution of the Benicàssim area (Maestrat basin, NE Spain): insights from fracture and vein analysis. Geogaceta 51(7): 79-82. 
Gregg, J.M. \& Shelton, K.L. 1990. Dolomitization and dolomite neomorphism in the back reef facies of the Bonneterre and Davis formations (Cambrian), southeastern Missouri. Journal of Sedimentary Research 60(4): 549562.

Henderson, A.L., Najman, Y., Parrish, R., Mark, D.F. \& Foster, G.L. 2011. Constraints to the timing of India-Eurasia collision; A re-evaluation of evidence from the Indus Basin sedimentary rocks of the Indus-Tsangpo Suture Zone, Ladakh, India. Earth-Science Reviews 106(3-4): 265-292.

Hauck, M.L., Nelson, K.D., Brown, L.D., Zhao, W. \& Ross, A.R. 1998. Crustal structure of the Himalayan orogen at 90 east longitude from Project INDEPTH deep reflection profiles. Tectonics 17(4): 481-500.

Hsü, K.J. 1967. Chemistry of dolomite formation. In Carbonate Rocks, edited by Chilingar, G.V. Bissel, H.J. \& Fairbridge, R.W. Elsevier, Amsterdam. pp. 169-191.

Huang, S.J., Shi, H., Mao, X.D., Zhang, M., Shen, L.C. \& Wu, W.H. 2003. Diagenetic alteration of Earlier Palaeozoic marine carbonate and preservation for the formation of sea water. Journal-Chengdu University of Technology 30: 9-18 (in Chinese with English abstract).

Kakemem, U., Jafarian, A., Husinec, A., Adabi, M.H. \& Mahmoudi, A. 2021. Facies, sequence framework, and reservoir quality along a Triassic carbonate ramp: Kangan Formation, South Pars Field, Persian Gulf Superbasin. Journal of Petroleum Science and Engineering 198: 108166.

Koeshidayatullah, A., Corlett, H., Stacey, J., Swart, P.K., Boyce, A. \& Hollis, C. 2020. Origin and evolution of fault-controlled hydrothermal dolomitization fronts: A new insight. Earth and Planetary Science Letters 541: 116291.

Khan, M.A., Ahmed, R., Raza, H.A. \& Kemal, A. 1986. Geology of petroleum in Kohat-Potwar Depression, Pakistan. AAPG Bulletin 70(4): 396-414.

Land, L.S. 1998. Failure to precipitate dolomite at $25{ }^{\circ} \mathrm{C}$ from dilute solution despite 1000-fold oversaturation after 32 years. Aquatic Geochemistry 4(3): 361-368.

Lavé, J. \& Avouac, J.P. 2000. Active folding of fluvial terraces across the Siwaliks Hills, Himalayas of central Nepal. Journal of Geophysical Research: Solid Earth 105(B3): 5735-5770.

Leech, M.L., Singh, S., Jain, A.K., Klemperer, S.L. \& Manickavasagam, R.M. 2005. The onset of India-Asia continental collision: Early, steep subduction required by the timing of UHP metamorphism in the western Himalaya. Earth and Planetary Science Letters 234(1-2): 83-97.

Lucia, F.J. \& Major, R.P. 1994. Porosity evolution through hypersaline reflux dolomitization. Dolomites: A Volume in Honour of Dolomieu, edited by Purser, B., Tucker, M. \& Zenger, D. Wiley Online Library. pp. 325-341. https://doi. org/10.1002/9781444304077.ch18.

Machel, H.G. \& Anderson, J.H. 1989. Pervasive subsurface dolomitization of the Nisku Formation in central Alberta. Journal of Sedimentary Research 59(6): 891-911. https://doi.org/10.1306/212F90AC-2B24-11D78648000102C1865D.
Machel, H.G. \& Lonnee, J. 2002. Hydrothermal dolomite - A product of poor definition and imagination. Sedimentary Geology 152(3-4): 163-171.

Martín-Martín, J.D., Gomez-Rivas, E., Bover-Arnal, T., Travé, A., Salas, R., MorenoBedmar, J.A., Tomás, S., Corbella, M., Teixell, A., Vergés, J. \& Stafford, S.L. 2013. The upper Aptian-lower Albian syn-rift carbonate succession of the southern Maestrat Basin (Spain): Facies architecture and fault-controlled strata-bound dolostones. Cretaceous Research 41: 217-236.

Mazzullo, S.J. 1992. Geochemical and neomorphic alteration of dolomite: A review. Carbonates and Evaporites 7(1): 21-37.

McDougall, J.W., Hussain, A. \& Yeats, R.S. 1993. The main boundary thrust and propagation of deformation into the foreland fold-and-thrust belt in northern Pakistan near the Indus River. Geological Society, London, Special Publications 74(1): 581-588.

McKenzie, D.P. \& Selater, J.G. 1973. The evolution of the Indian Ocean. Scientific American 228(5): 62-74.

Montaron, B. 2008. Confronting carbonates. Oil Review Middle East 5(1): 132-135.

Ngia, N.R., Hu, M. \& Gao, D. 2019. Tectonic and geothermal controls on dolomitization and dolomitizing fluid flows in the Cambrian-Lower Ordovician carbonate successions in the western and central Tarim Basin, NW China. Journal of Asian Earth Sciences 172: 359-382.

O’Brien, P.J., Zotov, N., Law, R., Khan, M.A. \& Jan, M.Q. 2001. Coesite in Himalayan eclogite and implications for models of India-Asia collision. Geology 29(5): 435-438.

Purser, B.H., Tucker, M.E. \& Zenger, D.H. 1994. Problems, progress and future research concerning dolomites and dolomitization. Dolomites: A Volume in Honour of Dolomieu 21: 3-20.

Rehman, H.U., Seno, T., Yamamoto, H. \& Khan, T. 2011. Timing of collision of the Kohistan-Ladakh Arc with India and Asia: Debate. Island Arc 20(3): 308-328. https://doi. org/10.1111/j.1440-1738.2011.00774.x.

Ronchi, P., Masetti, D., Tassan, S. \& Camocino, D. 2012. Hydrothermal dolomitization in platform and basin carbonate successions during thrusting: A hydrocarbon reservoir analogue (Mesozoic of Venetian Southern Alps, Italy). Marine and Petroleum Geology 29(1): 68-89.

Rosenbaum, J. \& Sheppard, S.M.F. 1986. An isotopic study of siderites, dolomites and ankerites at high temperatures. Geochimica et Cosmochimica Acta 50(6): 1147-1150.

Saboor, A., Haneef, M., Hanif, M. \& Swati, M.A.F. 2020. Sedimentological attributes of the Middle Jurassic peloidsdominated carbonates of eastern Tethys, lesser Himalayas, Pakistan. Carbonates and Evaporites 35(4): 1-17.

Shah, M.M., Ahmed, W., Ahsan, N. \& Lisa, M. 2016. Faultcontrolled, bedding-parallel dolomite in the middle Jurassic Samana Suk Formation in Margalla Hill Ranges, Khanpur area (North Pakistan): Petrography, geochemistry, and petrophysical characteristics. Arabian Journal of Geosciences 9(5): 405. 
Sibley, D.F. \& Gregg, J.M. 1987. Classification of dolomite rock textures. Journal of Sedimentary Research 57(6): 967-975.

Swennen, R., Dewit, J., Fierens, E., Muchez, P., Shah, M., Nader, F. \& Hunt, D. 2012. Multiple dolomitization events along the Pozalagua Fault (Pozalagua Quarry, Basque-Cantabrian Basin, Northern Spain). Sedimentology 59(4): 1345-1374.

Tahirkheli, R.A.K. 1982. Geology of the Himalaya, Karakoram and Hindukush in Pakistan. Special Issue, Geological Bulletin of the University of Peshawar 15. p. 51.

Tahirkheli, R.A.K. 1979. Geology of Kohistan and adjoining Eurasian and Indo-Pakistan continents, Pakistan. In Geology of Kohistan, edited by Tahirkheli, R.A.K. \& Jan, M.Q. Special Issue, Geological Bulletin of the University of Peshawar 11. pp. 1-30.

Tucker, M.E. \& Wright, V.P. 1990. Carbonate Sedimentology. Oxford: Blackwell Publishing Ltd.

Ullah Khan, E., Saleem, M., Naseem, A.A., Ahmad, W., Yaseen, M. \& Khan, T.U. 2020. Microfacies analysis, diagenetic overprints, geochemistry, and reservoir quality of the Jurassic Samanasuk Formation at the Kahi Section, Nizampur Basin, NW Himalayas, Pakistan. Carbonates and Evaporites 35(3): 1-17.

Veizer, J. 1983. Trace elements and isotopes in sedimentary carbonates. Reviews in Mineralogy 11: 265-300.

Wadood, B., Khan, S., Liu, Y., Li, H. \& Rahman, A. 2021. Investigating the impact of diagenesis on reservoir quality of the Jurassic shallow shelfal carbonate deposits: Kala Chitta Range, North Pakistan. Geological Journal 56(2): 1167-1186.

White, D.E. 1957. Thermal waters of volcanic origin. Geological Society of America Bulletin 68(12): 637-1658.
Yaseen, M., Wahid, S., Ahmad, S., Rehman, G., Ahmad, J., Anjum, M.N. \& Mehmood, M. 2021. Tectonic evolution, prospectivity and structural studies of the hanging wall of Main Boundary Thrust along Akhurwal-Kohat transect, Khyber Pakhtunkhwa: Implications for future exploration. Arabian Journal of Geosciences 14(4): 1-17.

Emad Ullah Khan, Abbas Ali Naseem* Maryam Saleem, Faisal Rehman, Syed Waseem Sajjad \& Tahir Azeem

Department of Earth Sciences

Quiad-e-Azam University Islamabad

Pakistan

Emad Ullah khan

Department of Geology

Abdul Wali Khan University Mardan, KP

Pakistan

Maryam Saleem

Department of Earth \& Environmental Sciences

Bahria University, Islamabad

Pakistan

Waqar Ahmad

Department of Earth \& Atmospheric Sciences

University of Alberta

Canada

*Corresponding author; email: abbasaliqau@gmail.com

Received: 11 November 2020

Accepted: 8 March 2021 